\title{
Investigating the anti-acne potential of endophytic bacterial extracts isolated from Mangifera casturi in indigenous South Borneo, Indonesia
}

\author{
Julius Riyanto, Sogandi* \\ Faculty of Pharmacy, 17 Agustus 1945 University, Jakarta 14350, Indonesia
}

Article history:

Submitted 14 September 2020

Accepted 13 October 2020

Published 24 December 2020

Keywords:

16s rRNA

Molecular

PCR

Propionibacterium acnes

Screening

*Corresponding author:

E-mail:

sogandi@uta45jakarta.ac.id

\begin{abstract}
Endophytic bacteria are beneficial microorganisms living in the tissues system of various parts of a plant, including fruits, leaves, twigs, and roots. The bacteria are stated as forming colonies without causing any damage to the plant. Thus, this study aimed at isolating endophytic bacterial from the leaves, barks, and fruits of Kasturi plant (Mangifera casturi), screening its endophytic bacteria, determining the potential of those endophytic bacteria, identifying 16S rRNA and analyzing potential growth of the bacteria. The isolated endophytic bacteria appeared to show potential activity against pathogenic bacteria Propionibacterium acnes with disc-diffusion methods. Besides, the observations on bacterial activities showed isolate L2, S2 and F4 isolated from leaves, bark and fruits, respectively, as the most potent producers of antibacterial compounds. Technically, those activities were indicated by the formation of clear zones. Molecular identification was investigated by applying PCR amplification on 16S rRNA gene. Furthermore, the isolate L2 was identified as Enterobacter cloacae with 99\% sequence similarities; however, isolates S2 and F4 were identified as Escherichia coli. Therefore, these findings suggested that the identified strains would contribute to any further searches for new sources of anti-acne substances.
\end{abstract}

\section{Introduction}

Acne has been observed to often occur during puberty, which ranges between 10-17 years old for women and 14-19 years old for men (Lynn et al., 2016). Almost everyone has experienced acne vulgaris, which usually begins at puberty age. In a survey, acne is dominantly occurred to women aged 18-20 years and located on the face (Skroza et al., 2018). Acne is acknowledged as both a health and an aesthetical problem many young people have been worrying about. Despite not being a serious medical issue, acne is considered as introducing a psychological impact on the decrease of a person's confidence.

The pathogenesis of acne includes four factors, including follicular epidermal hyperproliferation that results in follicular blockage, excessive sebum production, inflammation, and Propionibacterium acnes activity. Propionibacterium acnes plays a role in the pathogenesis of acne by producing lipases, breaking down free fatty acids from skin lipids. These fatty acids expectedly cause tissue inflammation when in 
contact with the body's immune system and promote the occurrence of acne problems (Khan et al., 2009). According to research conducted by Sinnot (2016), people experiencing acne problems were reported to receive treatments with tetracycline, erythromycin, or clindamycin antibiotics (Sinnot et al., 2016). However, the prolonged use of antibiotics has been known to cause bacterial resistance and organ damage (Fernández et al., 2019).

Kalimantan mango (Mangifera casturi), which is popularly known as Kasturi plant, has been recognized to contain compounds with medicinal benefits (Fakhrudin et al., 2015) including terpenoids, saponins, and steroids in its stem (Chabib et al., 2018). In particular, the bark of Kasturi plant contains flavonoid compounds, alkaloids, phenols, and steroids (Sutomo et al., 2014). Some research results indicate that flavonoid, terpenoid, steroid, and saponin compounds have been observed to perform antibacterial activity against Staphylococcus aureus and Escherichia coli (Nurunnabi et al., 2018).

However, isolating these bioactive compounds requires a significant amount of biomass. A known alternative solution to overcome the problems is through the utilization of endophytic bacteria in plant tissues. Endophytic bacteria are beneficial microorganisms living in the internal tissues of a plant without causing direct and negative effects on their host plant. In other words, there is a mutualistic symbiosis between endophytic bacteria and host plants (Alvin et al., 2014).

Technically, endophytic bacteria produce rare and important bioactive compounds for their host plants, reducing challenges to grow rare and long lifespan plants. In the long haul, it would significantly support the protection of the world's biodiversity (Brader et al., 2014). In general, using bacteria as a source of biological products would facilitate the process and reduce production costs to ultimately result in products at lower prices. The ability of endophytic bacteria to produce secondary metabolites in accordance with their host plants hence offers a huge and reliable opportunity to produce secondary metabolites (Abdalla \& Matasyoh, 2014). In the literature, various studies have attempted to focus on the potential of bioactive compounds contained in endophytic bacteria. Endophytic bacteria that can produce broad-spectrum antibiotics include those isolated from Noni fruits. These bacteria produce Pyrazine that actively inhibits Staphylococcus aureus, Escherichia coli, Shigella dysenteriae, and Streptococcus mutans (Sogandi \& Nilasari, 2019). Besides, the microspores of endophytic bacterium Pestalotiopsis isolated from Taxus plants can produce Paclitaxel, which is known as being effective to act as an anticancer (Strobel et al., 2002).

This study particularly aimed at isolating endophytic bacteria from the leaves, bark, and fruit of Kalimantan mango plant (Mangifera casturi). Besides, this study attempted to identify the potentials of isolated endophytic bacteria through their antibacterial activities and to analyze the potential growth of the bacteria.

\section{Materials and Methods \\ Sample preparation}

Mango casturi was collected from Gambut, Banjarmasin, South Borneo, Indonesia. Leave, bark, and fruits Mango casturi was rinsed using sterile water and immersed in $70 \%$ ethanol for 5 minutes and then put in the plastic containing sterile and transported to the laboratory for further investigation.

\section{Isolation of endophytic bacteria}

First, samples underwent surface-sterilized protocol. In practice, samples were washed through a running flow of tap water. Next, the washed samples were put into a $2 \%$ sodium hypochlorite for 5 minutes. Then, they have washed again by using distilled water. The latter two steps were repeated three times. At the end of the third repetition, these samples were washed with $70 \%$ ethanol and left in an openair to let the ethanol get completely evaporated. After the evaporation, samples were cut into small pieces $(1 \times 1 \mathrm{~cm})$ and placed on the surface of tryptic soy agar (TSA) plates supplemented with nystatin. After that, they were incubated at $30^{\circ} \mathrm{C}$ temperature for 72 hours. The plates were checked every day after inoculation. Then, endophytic bacteria were taken, purified, numbered, transferred separately to 
nutrient agar slants, and kept at $4{ }^{\circ} \mathrm{C}$ for further investigation (Sogandi \& Nilasari, 2019).

\section{Screening for potential isolates}

All endophytic bacteria isolates taken from leaves, bark, and fruits were grown in a $10 \mathrm{~mL}$ of nutrient broth medium for $48 \mathrm{~h}$ at $37^{\circ} \mathrm{C}$ temperature with a mild shaking (150 rpm). Next, cell-free supernatant (CFS) was prepared by centrifugation at $12000 \mathrm{~g}, 4^{\circ} \mathrm{C}$ for 5 minutes. Technically, antibacterial activity was determined against Propionibacterium acnes bacteria ATCC 37533. The test on the activity was conducted by using the disc diffusion method (Sogandi et al., 2020). Propionibacterium acnes was grown on a Blood Agar (BA) medium. Nutrient broth sterile was used as a negative control, while ampicillin (10 $\mu \mathrm{g} /$ disc) was used as a positive control. In the test, each bacterial isolate was mixed with sterile nutrient agar and transferred into Petri dishes to form a solid plate.

The discs (diameter $6 \mathrm{~mm}$ ) containing 30 microliter supernatants were put on surface agar plates to then be incubated at $37^{\circ} \mathrm{C}$ for 24 hours. All sample treatments and controls were performed in three replications. At the end of incubation, diameters of clear inhibition zones were measure. Isolate(s) of Endophytic bacteria showing the highest clear zone against bacterial test was stated as a potential isolate(s).

\section{Growing the potential isolated (s)}

The potential isolate(s) was subcultured in a nutrient broth medium at $37^{\circ} \mathrm{C}$ temperature for 12 hours with a mild shaking at $150 \mathrm{rpm}$. Next, $500 \mu \mathrm{L}$ aliquot of potential isolates were cultured by applying a $500 \mathrm{~mL}$ nutrient broth medium in a $1 \mathrm{~L}$ flask and incubated at $37{ }^{\circ} \mathrm{C}$ temperature for 48 hours. Then, optical density $(600 \mathrm{~nm})$ was taken every 2 hours (Triandriyani et al, 2020).

\section{Extraction of a secondary metabolite of pon- tential isolate}

Cell-free supernatants for the antibacterial assay were prepared by growing each potential isolate from leaves, bark and fruits $(1 \%, v / v)$ into $300 \mathrm{~mL}$ nutrient broth medium and incubated at $37^{\circ} \mathrm{C}$, shaker $150 \mathrm{rpm}$ for $32 \mathrm{~h}$ (early stationery phase). The cells were harvested with centrifuged at $12000 \mathrm{~g}$ for $10 \mathrm{~min}$. Then, the extract was ready to be screened for antibacterial activity.

\section{Antibacterial and Minimum Inhibitory Con- centration (MIC) assay}

Antibacterial activity of the secondary metabolite of potential isolates against Propionibacterium acnes was analyzed by applying the disc diffusion method. Technically, plates of blood agar medium were prepared by pouring $20 \mathrm{~mL}$ of the molten media containing bacterial test Propionibacterium acnes into sterile plates. After 15 minutes, $30 \mu \mathrm{L}$ supernatants were briefly touched down to the surface of paper discs. The discs, except two of them, were then put on agar plates surface and incubated at 37 ${ }^{\circ} \mathrm{C}$ temperature. As a negative control, one of two excluded discs was added with dimethyl sulfoxide (DMSO). Meanwhile, ampicillin (10 $\mu \mathrm{g} / \mathrm{dis}$ ) was added to the last excluded disc to act as a positive control. After the incubation period, the inhibition zone around each disc was measured (in millimeter) by using a transparent ruler. The measurements were performed three times for each disc.

Furthermore, minimum inhibitory concentration (MIC) was analyzed by applying the microdilution technique at various concentrations of the extracts $(5 ; 10 ; 15 ; 20 ; 25$; and $30 \%)$. In the analysis, each extract was dissolved in DMSO (dimethyl sulfoxide). Meanwhile, various positive controls were prepared to only contain inoculum and sterile DMSO solutions without any added extracts for ensuring no antibacterial effect. Besides, negative controls were also prepared to contain extract solutions and sterile medium for ensuring no contamination. The MIC analysis was conducted in a test tube containing $5 \mathrm{~mL}$ of NB media. The test tube was then incubated at $37^{\circ} \mathrm{C}$ temperature for 24 hours. Then, the absorbance was measured at $600 \mathrm{~nm}$ wavelength. The concentration of the sample in a particular test tube with the closest absorbance value to the positive control determined the MIC value. 


\section{Analysis of protein and nucleid acid leaks}

The suspension of bacterium Propionibacterium acnes aged 14 hours added cell-free supernatant to each potential isolate at 0 (control), 1 MIC, and 2 MIC concentrations. The test solution was put into an incubator and incubated at $37^{\circ} \mathrm{C}$ temperature. After 24 hours, the bacterial culture was centrifuged at $6000 \mathrm{rpm}$ for 5 minutes to separate supernatant from cell sediment. The absorbance of the supernatant was measured by using a spectrophotometer at two different wavelengths. Measurement at $260 \mathrm{~nm}$ wavelength was conducted to observe the release of nucleic acids, while the $280 \mathrm{~nm}$ wavelength setting was applied to observe protein that emerged from the cells of test bacteria. An increase in the absorbance value after treatment indicated the test bacteria to have undergone lysis and leakage, hence making genetic materials, which took the form of nucleic acids and proteins, scattered and leave the cells (Suhendar et al., 2019).

\section{Molecular identification}

\section{DNA extraction}

The total genomic DNA of the potential isolate was isolated from $5 \mathrm{~mL}$ culture medium broth. Bacterial cells were collected by centrifugation at $6000 \mathrm{~g}$ for $1 \mathrm{~min}$. The pellet was resuspended with $500 \mu \mathrm{L}$ buffer extraction (10 $\mathrm{mM}$ Tris- $\mathrm{HCl} \mathrm{pH}$ 8.0, $1 \mathrm{mM}$ EDTA, $60 \mathrm{mg} \mathrm{mL}^{-1}$ lysozyme) and then incubated at $37^{\circ} \mathrm{C}$ for $1 \mathrm{~h}$. After incubation, $200 \mu \mathrm{L}$ of $10 \%$ sodium dodecyl sulfate, $100 \mu \mathrm{L}$ of $5 \mathrm{M}$ sodium chloride, and $80 \mu \mathrm{L}$ of $10 \% \mathrm{CTAB}$ were added and vortex to mix. The mixture was then incubated at 60 ${ }^{\circ} \mathrm{C}$ for $30 \mathrm{~min}$. After that, an equal amount of chloroform $(1: 1 \mathrm{v} / \mathrm{v})$ was added to the mixture and vortex. Centrifugation was conducted at $13000 \mathrm{~g}$ for $3 \mathrm{~min}$. The supernatant was collected and 1:1 (v/v) ethanol was added and then centrifuged at $13000 \mathrm{~g}$ for $3 \mathrm{~min}$. The filtrate was removed, and the pellet-contained DNA was dissolved with $50 \mu \mathrm{L}$ of TE buffer $\mathrm{pH}$ 8.0 (Sogandi et al., 2019).

Polymerase Chain Reactions (PCR) amplification

This PCR following PCR master mix protocol, Qiagen HotStarTaq Plus Master Mix Kit with primer 16s rRNA 27F and 1492R. The PCR amplification reaction is as follows: The reaction involved one cycle at $95{ }^{\circ} \mathrm{C}$ for 5 minutes, followed by 35 cycles with a step of denaturation at $94{ }^{\circ} \mathrm{C}$ for 30 seconds, step annealing at $52{ }^{\circ} \mathrm{C}$ for 1 minute, and step extension at $72{ }^{\circ} \mathrm{C}$ for 1 minute, followed by one cycle at $72{ }^{\circ} \mathrm{C}$ for 10 minutes.

The PCR products were sent to Macrogen, Korea for sequencing. The sequences were trimmed and assembled by using the DNA MAN V.9 program. Furthermore, the sequences were subjected to BLAST on NCBI and species identification. The neighbor-joining method was used for constructing the phylogenetic tree with a bootstrap value of 1,000 replication by using MEGA 7.0 software (Tamura et al., 2011).

\section{Results and Discussion}

A prior study had attempted to isolate endophytic bacteria from Noni fruits. An observation of the antimicrobial activity of bacterial extracts showed that these extracts offered the potential to act as alternative sources for biomedical therapy (Sogandi \& Nilasari, 2019). In this study, fifteen endophytic bacterial isolates were selected according to their respective morphological characteristics as parts of Mangifera casturi. Technically, L1, L2, L3, L4, and L5 were isolated from the leaves, while isolates B1, B2, B3, B4 and B5 were from the bark. Then, $F 1, F 2, F 3, F 4$ and F5 were isolated from the fruits. These isolates confirmed the work of Lodewyckx et al. (2002), which argued that endophytic bacteria could technically be isolated from plant roots, leaves, stems, flowers, fruits and seeds.

\section{Screening of potential isolates}

Fifteen isolates of endophytic bacteria were screened for their antibacterial activity against $P$. acnes by applying the disc diffusion method. Disc diffusion assay revealed crude extracts of endophytic bacteria gathered from leaves, bark, and fruits as being able to inhibit the growth of $P$. acne pathogen. The result supported Strobel and Daisy's work (2002), which suggested endophytic bacteria as having the capability to synthesize pharmacologically active compounds as the result of their close endophytic host association and interactions (Strobel et al., 2002). In this study, isolates L2, $\mathrm{B} 2$, and F4, which were respectively taken from 
leaves, bark and fruits, were found to get inhibited with the maximum inhibition zone (Table 1). In other words, there was presumed dominancy of an organism related to the production of secondary metabolites functioning as a chemical defense. Therefore, L2, B2, and F4 isolates were selected as potential isolates for further investigation.

Table 1. Screening of antibacterial activity endophytic bacteria isolated from leave (L), bark (B), and fruits $(F)$

\begin{tabular}{ccc}
\hline Origin & Bacteria Code & Zone of inhibition $(\mathrm{mm}) \pm$ standard deviation $(\mathrm{SD})$ \\
\hline \multirow{4}{*}{ Leave } & L1 & $7.31 \pm 0.01$ \\
& L2 & $8.87 \pm 0.05$ \\
& L3 & $7.60 \pm 0.05$ \\
& L4 & $8.28 \pm 0.02$ \\
L5 & $7.33 \pm 0.01$ \\
\hline \multirow{5}{*}{ Bark } & B1 & $9.38 \pm 0.07$ \\
& B2 & $10.46 \pm 0.03$ \\
& B3 & $9.87 \pm 0.07$ \\
& B4 & $8.16 \pm 0.04$ \\
Fruit & B5 & $9.53 \pm 0.04$ \\
\hline & F1 & $8.31 \pm 0.05$ \\
& F2 & $9.43 \pm 0.02$ \\
& F3 & $8.53 \pm 0.02$ \\
& F4 & $9.88 \pm 0.01$ \\
& F5 & $9.00 \pm 0.05$ \\
\hline
\end{tabular}

\section{Production of secondary metabolite}

Measurement results of the cell density of the potential isolates were provided in Figure 1. Increased biomass for isolates L2, B2, and F4 were observed with a $600 \mathrm{~nm}$ OD, showing increases from 0.1 at the $12^{\text {th }}$ hour of incubation to its peak (1.2) at the $32^{\text {nd }}$ hour, and gradually decreased until 0.8 at the $36^{\text {th }}$ hour of incubation. The growth of biomass discovered the beginning of the log phase for L2, B2 and F4 isolates to occur at the $12^{\text {th }}$ hour. In other words, an exponential phase occurred during 14-26 hours of incubation.

After the $28^{\text {th }}$ hour, each isolate experienced a stationary phase until the $32^{\text {nd }}$ hour of incubation. Looking at the result, secondary metabolites were produced after being incubated for at least 28 hours, confirming a common fact in which secondary metabolites were commonly produced in the late growth phase (Cho et al., 2002). Besides, it supported prior research that suggested secondary metabolites from bacteria to usually be produced at the end of the exponential phase or at the beginning of the stationary phase (Sogandi \& Nilasari, 2019). The decaying phase of an isolate began to appear after 34 hours when the OD600 gradually decreased until 0.8 at the $36^{\text {th }}$ hour of incubation. Furthermore, secondary metabolites produced by each potential isolate were harvested at the beginning of the exponential phase (30 $30^{\text {th }}$ hour; Figure 1 ). 
A

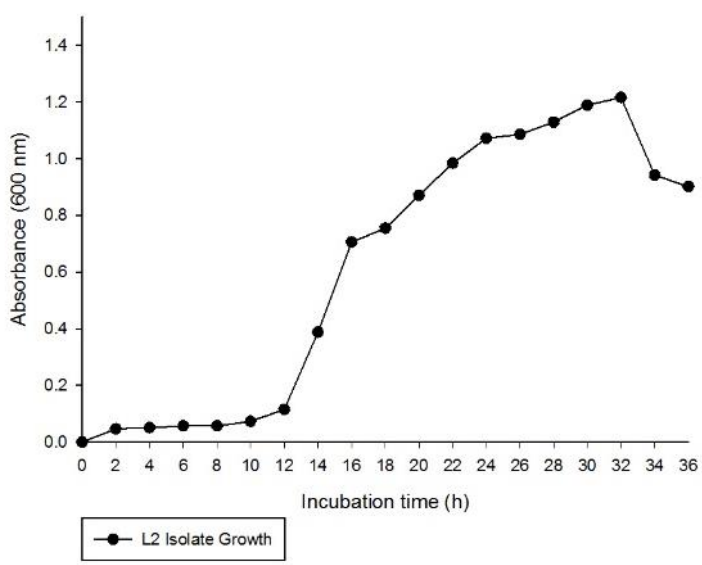

B

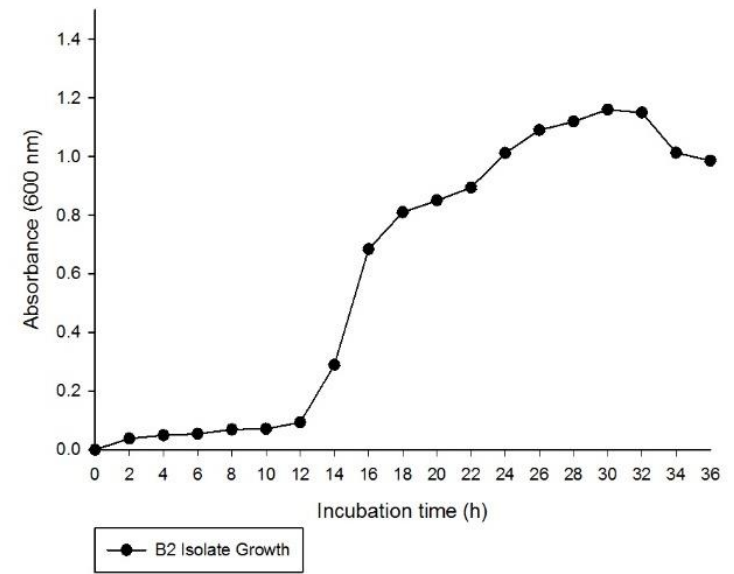

$\mathrm{C}$

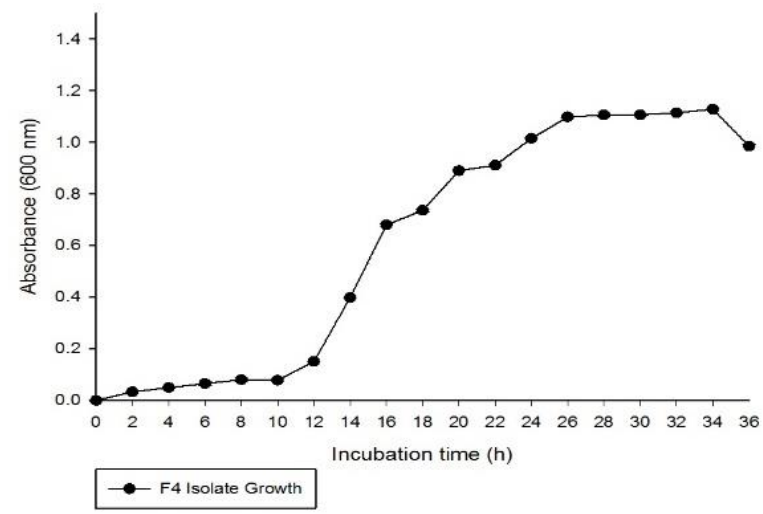

Figure 1. Growth of potential isolate from leave (L2; A), bark (B2; B), and fruit (F4; C) in nutrient broth medium at $37^{\circ} \mathrm{C}$

\section{Minimum Inhibitory Concentration (MIC)}

Minimum Inhibitory Concentration (MIC) was measured on the crude extracts of secondary metabolites produced by potential isolates from Mangifera casturi against the growth of $P$. acne. The measurement revealed $\leq 20 \%$ MIC for extracts gathered from leaves, bark, and fruits. Extracts were classified based on their measured MIC values. A strong inhibitor was 
given for those having MIC $\leq 10 \%$, while a moderate inhibitor was given for those having activity between $10-30 \%$. Then, a weak inhibitor was given for those having MIC above 30\% (Wong et al., 2012). In general, crude extracts of the secondary metabolites of potential isolates were observed to be moderate inhibitors against P. acne (Table 2).

Table 2. Minimum inhibitor concentration (MIC) of potential isolate

\begin{tabular}{cccc}
\hline \multirow{2}{*}{ Concentration (\%) } & \multicolumn{3}{c}{ Absorbance (600 nm) } \\
\cline { 2 - 4 } & L2 & B2 \\
\hline Negative control (DMSO) & \multicolumn{3}{c}{$1.21 \pm 0.09$} \\
\hline Positive control (ampicillin) & $0.15 \pm 0.03$ \\
\hline 5 & $1.06 \pm 0.12$ & $0.56 \pm 0.06$ & $0.61 \pm 0.03$ \\
\hline 10 & $1.05 \pm 0.10$ & $0.54 \pm 0.09$ & $0.62 \pm 0.04$ \\
\hline 15 & $0.94 \pm 0.01$ & $0.58 \pm 0.03$ & $0.66 \pm 0.01$ \\
\hline 20 & $0.33 \pm 0.07$ & $0.47 \pm 0.07$ & $0.56 \pm 0.04$ \\
\hline 25 & $0.27 \pm 0.05$ & $0.39 \pm 0.09$ & $0.58 \pm 0.05$ \\
\hline
\end{tabular}

\section{Identification of potential isolate}

In total, 3 isolates from leaves, bark, and fruits were selected as potential isolates. Furthermore, molecular identification was conducted by following the method as described in the research procedure, which was suggested by our study before (Sogandi et al., 2019). Genomic DNA was amplified by using $16 \mathrm{~S}$ rRNA
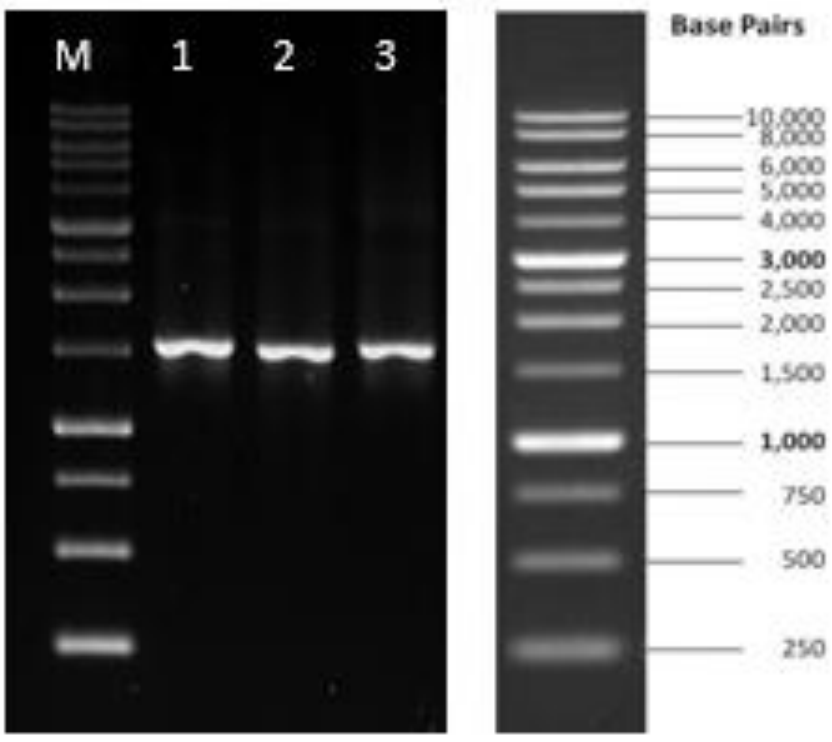

Figure 2. Gel electrophoresis of PCR product 16s rRNA gene from potential isolate L2 (1), B2 (2), and F4 (3). There is a $1500 \mathrm{bp}$ band from the sample and marker (M) is $1 \mathrm{~kb}$ used gene. PCR results were electrophoresed by applying $0.8 \%$ agarose gel at 100 volts for 60 minutes. Agarose gel was visualized under UV light. DNA bands were obtained on $\pm 1500 \mathrm{bp}$ (base pair). 
After being purified, the amplified DNA sequence was determined and aligned with base sequences taken from the NCBI database. Sequence alignment of potential isolates L2, B2, and F4 discovered $\pm 1370,1397$, and $1400 \mathrm{bp}$ of $16 \mathrm{~S}$ rRNA gene, respectively. A BLAST search in NCBI-GenBank showed the L2 isolate to have a maximum $100 \%$ identity of Enterobacter $s p$ strain ACP6 (accession number: MH915674.1), while B2 and F4 isolates were found to have respective $99.07 \%$ and $99.64 \%$ similarity with Escherichia coli strain ECS15 (Acc no. MN006357.1). These results had never been reported previously. Furthermore, the results of this study were taken to construct a phylogenetic tree for determining the relationship between species. Sequence alignments of observed bacteria with other bacterial sequences, which were taken from the NCBI-GenBank database, were conducted in Clustal X2. Next, the results of the alignment were inputted into NJPlot to construct a phylogenetic tree. The phylogenetic tree is constructed based on $16 \mathrm{~S}$ rRNA sequence hence revealed that L2 isolate belonged to the family Enterobacteriaceae and included in Enterobacter clade (Figure 3).

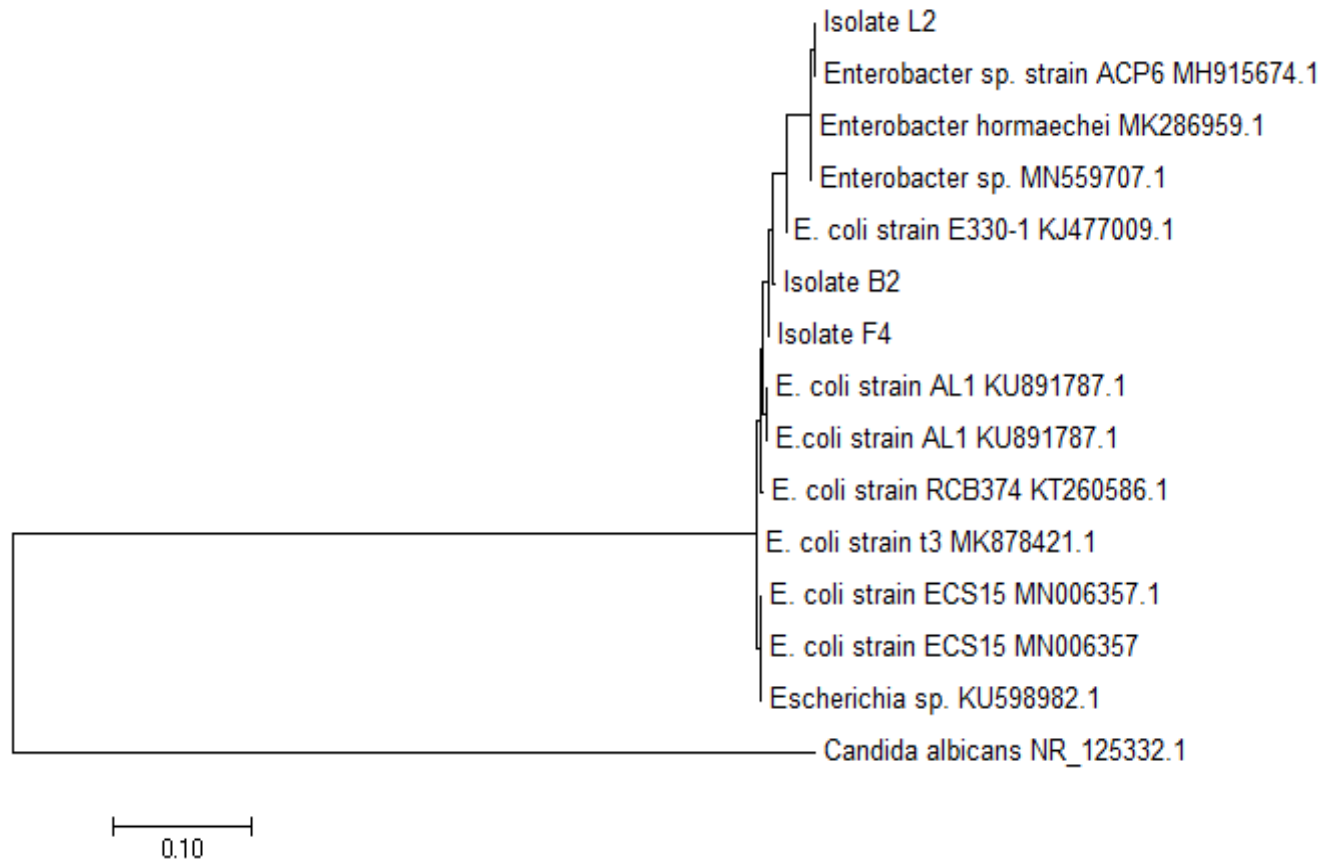

Figure 3. A cladogram resulted from the neighbor-joining method of $16 \mathrm{~s}$ rRNA sequence of potential isolate L2, B2, and F4 from Mangifera casturi and its allied taxa

Technically, Enterobacter is a Gram-negative bacterium, has anaerobic fluctuations, is rod-shaped, and motile. Enterobacter $s p$ is a bacterium producing protease, amylase, and cellulase enzymes. In general, protease has been used as probiotics to both humans and animals because it can suppress the growth of pathogenic bacteria. Furthermore, Enterobacter $s p$ has been reported as an endophytic and associated fungus in plants. For example, endophytic bacteria Enterobacter had been isolated from Aloe vera. Crude extracts and ethyl acetate fractions of its metabolites have been observed to perform antimicrobial activities against pathogenic bacteria Pseudomonas aeruginosa, Staphylococcus aureus, Bacillus cereus, Salmonella Typhimurium, Proteus vulgaris, Klebsiella pneumonia, Escherichia coli, Streptococcus pyogenes, and Candida albicans (Akinsanya et al., 2015).

Then, a study on the bioactive compounds of endophytic bacteria from Mangifera indica had screened those bacteria according to their morphology and biochemical analysis (Dasari et al., 2015). This study concluded that they might belong to Acinetobacter, Cyclobacterium and Cellulomonas genera, which had been observed to perform antibacterial activity against 
Escherichia coli, Salmonella typhi, Staphylococcus aureus, and Pseudomonas aeruginosa. Compounds particularly responsible for their antimicrobial properties included Mangiferin and gallic acid.

\section{Conclusion}

This study has discovered isolates L2, B2, and F4 of endophytic bacteria from Mangifera casturi to show potential bioactive activity against pathogenic bacteria Propionibacterium acnes. Besides, molecular identification revealed isolate L2 as Enterobacter, while isolates B2 and F4 were Escherichia coli. Looking at the results of this study, further researches needs to determine which bioactive compound offers growth-inhibiting activity against Propionibacterium acnes.

\section{Acknowledgment}

Authors would like to thank the Faculty of Pharmacy, University of 17 Agustus 1945, Jakarta, Indonesia, for providing facilities required to carry out this work.

\section{Competing Interest}

The authors declare no other competing interests.

\section{Authors Contribution}

SS was designed in this study. JR carried out laboratory work and analyzed data. SS advised about the laboratory technique and conducted manuscript proofreading before submission. All authors read and approved the final version of the manuscript.

\section{References}

Abdalla, M. A., \& Matasyoh, J. C. (2014). Endophytes as producers of peptides: an overview about the recently discovered peptides from endophytic microbes. Natural Products and Bioprospecting, 4(5), 257-270. https://doi.org/10.1007/s13659-0140038-y

Akinsanya, M.A., Goh, J. K., Lim, S. P., \& Ting, A. S. Y. (2015). Diversity, antimicrobial and antioxidant activities of culturable bacterial endophyte communities in Aloe vera. FEMS Microbiology Letters, 362(23). https://doi.org/10.1093/femsle/fnv184
Alvin, A., Miller, K. I., \& Neilan, B. A. (2014). Exploring the potential of endophytes from medicinal plants as sources of antimycobacterial compounds. Microbiological Research, 169(7-8), 483-495. https://doi.org/10.1016/j.micres.2013.12.009

Brader, G., Compant, S., Mitter, B., Trognitz, F., \& Sessitsch, A. (2014). Metabolic potential of endophytic bacteria. Current Opinion in Biotechnology, 27, 3037. https://doi.org/10.1016/i.copbio.2013.09.012

Chabib, L., Muhtadi, W. K., Rizki, M. I., Rahman, R. A., Suhendri, M. R., Hidayat, A. (2018). Potential medicinal plants for improve the immune system from Borneo Island and the prospect to be developed as nanomedicine. MATEC Web of Conferences, 154(04006). https://doi.org/10.1051/matecconf/201815404006

Cho, S. J. et al. (2002). Endophytic bacillus sp. Isolated from the interior of balloon flower root. Bioscience, Biotechnology and Biochemistry, 66(6), 1270-1275. https://doi.org/10.1271/bbb.66.1270

Dasari, T.R., Inamdar, S. M., \& Pawar, K. V. (2015). Study on production of bioactive compounds and plant promoting ability of endophytes isolated from Rosa sp. and Mangifera indica. International Journal of Current Microbiology and Applied Sciences, 4(2), 136-143. http://www.ijcmas.com.

Fakhrudin, N., Hastuti, S., Andriani, A., Widyarini, S., \& Nurrohmad, A. (2015). Study on the antiinflammatory activity of artocarpus altilis leaves extract in mice. International Journal of Pharmacognosy and Phytochemical Research, 7(6), 1080-1085. http://impactfactor.org/PDF/IJPPR/7/IJPPR,Vol7,Issue6,Article9.pdf

Fernández, J. (2019). Multidrug-resistant bacterial infections in patients with decompensated cirrhosis and with acute-on-chronic liver failure in Europe. Journal of hepatology, 70(3), 398-411. https://doi.org/10.1016/i.jhep.2018.10.027

Khan, Z. Z., \& Moore, T. A. (2009). Recurrent epidural abscess caused by propionibacterium acnes. Kansas Journal of Medicine, 2(4), 92-95. https://journals.ku.edu/kjm/article/download/11302/10709/

Lynn, D. D., Umari, T., Dunnick, C. A., \& Dellavalle, R. P. (2016). The epidemiology of acne vulgaris in late adolescence. Adolescent Health, Medicine and Therapeutics, 7(1), 13-25. https://doi.org/10.2147/AHMT.S5832

Nurunnabi, T., Al-Majmaie, S., Nakouti, I., Nahar, L., Rahman, S., Sohrab, M., Billah, M., Ismail, F., Sharples, G., \& Sarker, S. D. (2018). Antimicrobial activity of 
kojic acid from endophytic fungus Colletotrichum gloeosporioides isolated from Sonneratia apetala, a mangrove plant of the Sundarbans. Asian Pacific Journal of Tropical Medicine, 11(5), 350-354. https://doi.org/10.4103/1995-7645.233183

Sinnot, S. J., Bhate, K., Margolis, D.J., Langan, S. M. (2016). Antibiotics and acne: an emerging iceberg of antibiotic resistance? British Journal of Dermatology, 175, 1127-1128. https://doi.org/10.1111/bjd.15129

Skroza, N., Tolino, E., Mambrin, A., Zuber, S., Balduzzi, V., Marchesiello, A., Bernardini, N., Proietti, I., \& Potenza, C. (2018). Adult acne versus adolescent acne: a retrospective study of 1,167 patients. The Journal of clinical and aesthetic dermatology, 11(1), 21-25. https://pubmed.ncbi.nlm.nih.gov/29410726/

Sogandi., Fitrianingrum, M., \& Thursina, A. (2020). Identification of bioactive compound and antbacterial activity of noni fruit (Morinda citrifolia l) extract as inhibitor Propionibacterium acne. Buletin Penelitian Kesehatan, 48(1), 73-82. https://doi.org/10.22435/bpk.v48i1.2338

Sogandi., Mustopa, A. Z., Artika, I. M. (2019). The characterization of bacteriocins produced by Lactobacillus plantarum strains isolated from traditional fermented foods in Indonesia and the detection of its plantaricin-encoding genes. Indonesian Journal of Biotechnology, 24(1), 1-7. https://doi.org/10.22146/ijbiotech.42582

Sogandi., \& Nilasari, P. (2019). Isolation and molecular identification of endophytic bacteria from Noni fruits (Morinda citrifolia $l$ ) and their antibacterial activity. IOP Conference Series: Earth Environmental Science, 299, 1-11. https://doi.org/10.1088/1755$1315 / 299 / 1 / 012020$

Strobel, G., Ford, E., Worapong, J., Harper, J. K., Arif, A. M., Grant, D. M., Fung, P. C. W., \& Ming, W. C. R. (2002).
Isopestacin, an isobenzofuranone from Pestalotiopsis microspora, possessing antifungal and antioxidant activities. Phytochemistry, 60(2), 179-183. https://doi.org/10.1016/S0031-9422(02)00062-6

Suhendar, U., Fathurrahman, M., \& Sogandi. (2019). Antibacterial activity and mechanism of action of methanol extract from kasturi mango fruit (Mangifera casturi) on caries-causing bacterium Streptococcus mutans. Jurnal Kimia Sains dan Aplikasi, 22(6), 235241. https://doi.org/10.14710/iksa.22.6.235-241.

Sutomo, S., Wahyuono, S., Rianto, S., \& Yuswanto, A. (2014). Antioxidant activity assay of extracts and active fractions of kasturi fruit (Mangifera casturi Kosterm.) using 1, 1-diphenyl-2-picrylhydrazyl method. Journal of Natural Products, 7(1), 124-130. http://journalofnaturalproducts.com/Volume7/17_Res_paper-16.pdf

Tamura, K., Peterson, D., Peterson, N., Stecher, G., Nei, M., \& Kumar, S. (2011). MEGA5: molecular evolutionary genetics analysis using maximum likelihood, evolutionary distance, and maximum parsimony methods. Molecular Biology and Evolution, 28(10), 2731-2739. https://doi.org/10.1093/molbev/msr121

Triandriani, W., Saputri, D. D., Suhendar, U., \& Sogandi. (2020). Antioxidant activity of endophytic bacterial extract isolated from clove leaf (Syzygium aromaticum L.). Journal of Agriculture and Applied Biology, 1(1), 9 - 17. https://doi.org/10.11594/jaab.01.01.02

Wong, W. R., Oliver, A. G., \& Linington, R. G. (2012). Development of antibiotic activity profile screening for the classification and discovery of natural product antibiotics. Chemistry \& Biology, 19(11), 14831495. https://doi.org/10.1016/i.chembiol.2012.09.014. 